\title{
Analisis Potensi Sektor Ekonomi Dalam Upaya Peningkatan Pertumbuhan Ekonomi (Studi Empiris Pada Kabupaten dan Kota di Provinsi Gorontalo tahun 2012-2016)
}

\section{Ismail Ibrahim}

\begin{abstract}
Studi Pembangunan, Fakultas Ekonomi Universitas Gorontalo
\end{abstract} email: ismailibrahim1066@yahoo.com

\begin{abstract}
Analysis of Economic Sector Potential in Efforts to Increase Economic Growth (Empirical Study on Gorontalo Regency and Gorontalo City in Gorontalo Province in 2012-2016).

The purpose of this study is to analyze the potential of the economic sector in the development of Gorontalo Province, and To identify potential economic sectors with competitive advantage and specialization in Gorontalo Province. This research used the method is LQ (location Quotienf) and Shift Share (SS) analysis to identify economic sector in Gorontalo Province development, identifying potential sectors with competitive advantage. Aided by a time series of data that looks at GDP growth between the study area and the reference area. The result of research shows that in Gorontalo regency, the period of 2012-2016 which becomes the main base sector is agriculture sector, while for Gorontalo city which become the main base sector is gas and water supply sector, building sector and trade sector of hotel and restaurant. In addition, the sector contributes the largest as a contribution to the GDP and absorbing labor in the regency and municipalities so as to encourage the growth of GRDP value every year in the Province of Gorontalo
\end{abstract}

Keywords : Potential economic sector, economic growth

\section{PENDAHULUAN}

Secara filosofi suatu proses pembangunan dapat diartikan sebagai upaya yang sistematik dan berkesinambungan untuk menciptakan keadaan yang dapat menyediakan berbagai alternatif yang sah bagi pencapaian aspirasi setiap warga yang paling humanistik. Dengan perkataan lain proses pembangunan merupakan proses memanusiakan manusia, Rustiadi dkk, 2011, dikutip pada Umami (2014:1). 
Menurut pendapat Todaro (2006:22) yang menyatakan bahwa pembangunan harus dipandang sebagai suatu proses multidimensional yang mencakup berbagai perubahan mendasar atas struktur sosial, sikap-sikap masyarakat, dan institusi-institusi nasional, di samping tetap mengejar akselerasi pertumbuhan ekonomi, penanganan ketimpangan pendapatan, serta pengentasan kemisikinan. Jadi pembangunan suatu negara dapat dikatakan baik tidak hanya dilihat dari pertumbuhan ekonominya yang semakin meningkat saja, tetapi juga dilihat dari aspek-aspek lain sepeti yang telah tersebut di atas.

Salah satu hal yang menjadi permasalahan dalam pembangunan suatu negara adalah ketimpangan antar wilayah. Ketimpangan antar wilayah dapat terjadi di negara berkembang maupun negara maju. Meskipun suatu negara mempunyai pertumbuhan ekonomi yang terus meningkat, tetapi tidak menutup kemungkinan bahwa negara tersebut masih mengalami ketimpangan antar wilayah.

Namun perlu dipahami teori pertumbuhan ekonomi wilayah merupakan bagian terpenting dalam analisis ekonomi, karena pertumbuhan merupakan salah satu unsur utama pembangunan ekonomi wilayah dan mempunyai implikasi kebijakan yang cukup luas. Sasaran utama analisis pertumbuhan ekonomi ini adalah untuk menjelaskan mengapa suatu daerah dapat tumbuh cepat dan ada yang tumbuh lambat. Analisis pertumbuhan ekonomi wilayah ini juga dapat menjelaskan hubungan antara pertumbuhan ekonomi dan ketimpangan antar daerah, Sjafrizal (2014: 88)

Suatu daerah akan mengalami percepatan pertumbuhan apabila memiliki potensi sektor ekonomi yang mampu mengakselerasi pembangunan dan sektor-sektor yang lain (Rustiadi et al., 2011), dikutip pada Wisnu dan Wijaya (2014). Kemudian disampaikan bahwa untuk itu penentuan potensi sektor ekonomi dalam pembangunan daerah adalah penting dilakukan sebagai upaya pengalokasian sumberdaya yang tersedia dengan tepat. Pertumbuhan potensi sektor ekonomi di suatu daerah diyakini akan mendorong pertumbuhan dan perkembangan sektor-sektor ekonomi lain daerah setempat dan perekonomian daerah sekitarnya. Dalam hal ini daerah pengembangan potensi sektor ekonomi tersebut diharapkan pula akan meningkatkan penyerapan tenaga kerja dan sumberdaya daerah sekitar dan bagi daerah pengembangan sektor ekonomi unggulan sendiri akan meningkatkan ekspor produk dan jasa yang dihasilkan.

Makanya salah satu sasaran pembangunan ekonomi wilayah jangka panjang adalah terjadinya pergeseran pada struktur ekonomi wilayah yang terjadi akibat kemajuan pembangunan suatu wilayah. Tidak semua sektor dalam perekonomian memiliki kemampuan tumbuh yang sama. Oleh karena itu, perencana pembangunan memanfaatkan sektor-sektor basis yang dianggap dapat mendorong pertumbuhan ekonomi, Daryanto dan Hafizrianda (2010 : 20).

Di wilayah Provinsi Gorontalo, kantong kemiskinan terbesar berada di beberapa Kabupaten. Pengangguran juga cukup tinggi, pada data Sakernas tahun 2004 tercatat pengangguran di Gorontalo 
sebanyak 45.360 jiwa sementara pada data tercatat ada 57.412 jiwa. Dari aspek pendidikan, output pendidikan yang dicerminkan oleh Angka Partisipasi Kasar (APK) dan Angka Partisipasi Murni (APM) untuk semua tingkatan sekolah pada tahun 2002 dan 2005 umumnya berada di bawah nasional dan dibawah dua provinsi terdekatnya, Sulawesi Utara dan Sulawesi Tengah (World Bank, 2008).

Dengan demikian berdasarkan data tersebut maka patutlah dan terus membenah diri dengan kemampuan yang dimiliki berupa potensi wilayah agar dapat dimanfaatkan semaksimal mungkin dalam meningkatkan produksi (output) masyarakat sehingga hal ini akan dapat mengurangi angka kemiskinan tinggi, tetapi dapat merubah menjadi peningkatan pertumbuhan ekonomi pada setiap stre kehidupan masyarakat.

Berdasarkan latar belakang diatas maka rumusan masalah dalam penelitian ini sebagai berikut : Bagaimana menganalisis potensi sektor ekonomi dalam Upaya Pengembangan Provinsi Gorontalo

\subsection{Pengertian Potensi Sektor Ekonomi Wilayah}

Location Qoutient disingkat dengan LQ adalah suatu perbandingan tentang besarnya peranan suatu sektor/ komoditi di suatu daerah terhadap peraran sektor/ komoditi di daerah yang lebih tinggi. Dengan kata lain LQ menghitung share output sektor i di kabupaten dengan share output sektor i di provinsi. Metode analisis ini dapat digunakan untuk memproyeksikan pertumbuhan ekonomi suatu daerah dan sebagai alat analisis dalam riset pembangunan pedesaan (Tambunan, 1996). Analisis ini juga digunakan untuk menganalisis sumbangan (share) kecamatan ke kabupaten dan sektor yang mengalami kemajuan selama pengukuran. Hasil analisis shift share ini juga mampu menunjukkan keunggulan kompetitif suatu wilayah.

Ada tiga sumber penyebab pergeseran yaitu :

- Komponen share, menunjukkan kontribusi pergeseran total seluruh sektor di total wilayah agregat yang lebih luas

- Komponen proportional shift, menunjukkan pergeseran total sektor tertentu di wilayah agregat yang lebih luas

- Komponen differential shift, menunjukkan pergeseran suatu sektor tertentu di suatu wilayah tertentu.

Apabila komponen differential shift bernilai positif maka suatu wilayah dianggap memiliki keunggulan kompetitif karena secara fundamental masih memiliki potensi untuk terus tumbuh meskipun faktor-faktor ekternal (komponen share dan proportional shift) tidak mendukung

Salah satu indikator yang mampu menggambarkan keberadaan sektor basis adalah melalui indeks LQ (location Quotienf) yaitu indikator yang sederhana yang menunjukkan kekuatan atau besar kecilnya peranan suatu sektor dalam suatu daerah dibandingkan dengan daerah diatasnya atau wilayah referensi. Ada dua cara untuk mengukur LQ dari suatu sektor dalam suatu perekonomian wilayah yaitu melalui pendekatan nilai tambah atau PDRB (Produk Demestik 
Regional Bruto) dan tenaga kerja, Daryanto dan Hafizrianda (2010 : 21).

Adapun masing-masing pengukurannya akan dijabarkan sebagai berikut :

1. Pendekatan Tenaga Kerja

$$
\mathrm{LQ}=\frac{\mathrm{Li} / \mathrm{Lt}}{\mathrm{Ni} / \mathrm{Nt}}
$$

2. Pendekatan Nilai Tambah

$$
\mathrm{LQ}=\frac{\mathrm{Vi} / \mathrm{Vt}}{\mathrm{Yi} / \mathrm{Yt}}
$$

Dimana :

$\mathrm{Li}=$ jumlah tenaga kerja sektor i pada tingkat wilayah yang lebih rendah

Lt = total tenaga kerja pada tingkat wilayah yang lebih rendah

$\mathrm{Ni}=$ jumlah tenaga kerja sektor $\mathrm{i}$ pada tingkat wilayah yang lebih diatas

$\mathrm{Nt}=$ total tenaga kerja pada tingkat wilayah yang lebih diatas

$\mathrm{Vi}=$ nilai $\mathrm{PDRB}$ sektor $\mathrm{i}$ pada tingkat wilayah yang lebih rendah

$\mathrm{Vt}=$ total PDRB pada tingkat wilayah yang lebih rendah

$\mathrm{Yi}=$ nilai PDRB sektor i pada tingkat wilayah yang lebih atas

$\mathrm{Yt}=$ Total PDRB pada tingkat wilayah yang lebih atas

Dalam literature ekonomi wilayah disebutkan bahwa suatu sektor yang memiliki angka LQ > 1 maka sektor tersebut merupakan sektor basis yang menjadi kekuatan daerah untuk mengekpor produknya keluar daerah bersangkutan. Sebaliknya jika nilai LQ $<1$ maka sektor tersebut menjadi pengimpor sedangkan jika nilai $\mathrm{LQ}=1$ maka ada kecenderungan sektor tersebut bersifat tertutup karena tidak melakukan transaksi dari dan ke luar wilayah, namun kondisi seperti ini sulit ditemukan dalam sebuah perekonomian wilayah.

\subsection{Pengertian Pertumbuhan Ekonomi}

Teori pertumbuhan ekonomi menurut Sjafrizal (2014 : 88) membedakan teori pertumbuhan yang terdapat dalam teori makro, tetapi teori pertumbuhan ekonomi wilayah ini menekankan perhatiannya pada pertumbuhan ekonomi suatu daerah tertentu dan tidak pada suatu negara sebagaimana lazimnya pada analisis ekonomi makro tersebut. Disamping itu, Teori pertumbuhan ekonomi wilayah memasukkan unsur lokasi dan tata ruang secara eksplisit kedalam analisisnya.

Pertumbuhan ekonomi merupakan salah satu indikator keberhasilan pembangunan di suatu perekonomian. Kesejahteraan dan kemajuan suatu perekonomian ditentukan oleh besarnya pertumbuhan yang ditunjukkan oleh perubahan output nasional. Adanya perubahan output dalam perekonomian merupakan analisis ekonomi jangka pendek, Ma'ruf dan Wihastuti (2008). 
Menurut Todaro (2003:92) dalam pertumbuhan ekonomi suatu bangsa terdapat tiga komponen penentu utama yaitu: (i) akumulasi modal yang meliputi semua bentuk atau jenis investasi baru yang ditanamkan pada tanah, peralatan fisik, dan sumberdaya manusia; (ii) pertumbuhan penduduk yang meningkatkan jumlah angkatan kerja di tahun-tahun mendatang; (iii) kemajuan teknologi.

Menurut Kuznets dikutip pada Jhingan (2012:57) pertumbuhan ekonomi adalah kenaikan kapasitas dalam jangka panjang dari negara untuk menyediakan berbagai barang ekonomi kepada penduduknya. Kenaikan kapasitas itu sendiri ditentukan atau dimungkinkan oleh adanya kemajuan atau penyesuaian-penyesuaian teknologi, Institusional (kelembagaan), dan ideologis terhadap berbagai tuntutan keadaan yang ada.

Dikatakan Todaro (2012 : 57-65) cirri-ciri pertumbuhan ekonomi modern, Kuznets adalah sebagai berikut :

1. Laju pertumbuhan penduduk dan produk perkapita dimana bahwa kalau jumlah penduduk meningkat harus dibarengi dengan bertambahnya jumlah pendapatan perkapita

2. Peningkatan Produktifitas dimana pertumbuhan ekonomi yang meningkat nampak pada produk perkapita terutama terjadi perbaikan kualitas input yang meningkatkan efisiensi atau produktifitas perunit input.

3. Laju perubahan struktural dimana perubahan ini mencakup peralihan kegiatan pertanian ke nonpertanian, dari industri ke jasa, dari perusahaan perorangan menjadi perusahaan berbadan hukum serta perubahan startus kerja buruh.

4. Urbanisasi dimana pertumbuhan ini ditandai semakin banyak penduduk dinegara maju berpindah dari daerah pedesaan ke daerah perkotaan.

5. Ekspansi Negara Maju dimana pertumbuhan ini ditandai dengan ilmu dan pengetahuan modern mulai berkembang, revolusi industri tadinya terjadi di Inggris sekarang bergeser dan menyebar ke Eropa, jepang.

Masih dalam Jhingan (2012:67) dikatakan bahwa proses pertumbuhan ekonomi dipengaruhi oleh faktor yakni faktor ekonomi yang tergantung pada sumber alamnya, sumberdaya manusia, modal, organisasi, teknologi, pembagian kerja dan skala produksi sedangkan faktor non ekonomi yang tergantung pada faktor sosial, faktor manusia, faktor politik dan administratif.

Dalam Subandi (2011 : 47) mengatakan pada teori pertumbuhan Rostow membagi dalam 5 tahapan dan kemungkinan setiap negara berada dalam salah satu dari tahap-tahap pembangunan sebagai berikut :

1. Tahap masyarakat tradisional (the traditional Society)

2. Tahap prasyarat lepas landas (the precondition for take off)

3. Tahap lepas landas (the take off)

4. Tahap gerak menuju kematangan (the drive of maturity)

5. Tahap Konsumsi masa tinggi (the age of high mass consumption) 
Menurut Rostow bahwa adanya tiga macam tujuan masyarakat yang saling bersaing untuk mendapatkan sumber daya-sumber daya yang tersedia dan dukungan politik. Ketiga tujuan tersebut adalah sebagai berikut :

1. Memperbesar kekuasaan dan pengaruh negara tersebut keluar negeri dan kecendrungan ini dapat berakhir dengan penaklukan (invasi) atas negara-negara lain.

2. Menciptakan suatu Walfare state yaitu kemakmuran yang lebih merata kepada penduduknya dengan cara mengusahakan terciptanya pembagian pendapatan melalui sistim perpajakan yang progresif.

3. Mempertinggi tingkat konsumsi masyarakat dari konsumsi kebutuhan pokok yang sederhana seperti makanan, pakaian dan perumahan ketingkat konsumsi lebih tinggi meliputi barang konsumsi tahan lama dan barang mewah sekaligus.

Faktor-faktor yang mempengaruhi pertumbuhan wilayah secara secara tidak langsung yakni melalui aspek-aspek keputusan locational, terbentuknya sistim perkotaan dan mekanisme aglomerasi tetapi dapat dipengaruhi secara spesifik terkait dengan pertumbuhan ekonomi wilayah, Nugroho dan Dahuri (2012 : 57). Pertumbuhan dan perkembangan memiliki makna yang berbeda, namun menurut Parr (1999) didalam perkembangan wilayah senantiasa disertai perubahanperubahan struktural. Pertumbuhan dan perkembangan suatu wilayah merupakan suatu proses kontinyu hasil dari berbagai keputusan di dalam maupun mempengaruhi suatu wilayah. Proses yang terjadi sangat kompleks melibatkan aspek sosial, lingkungan dan politik.

\subsection{Kerangka Pemikiran}

Setiap daerah memiliki potensi ekonomi masing-masing yang dapat dikembangkan untuk meningkatkan perekonomian daerahnya. Tetapi tidak semua potensi ekonomi tersebut telah digali dan dimanfaatkan secara optimal. Provinsi Gorontalo yang terdiri dari 5 Kabupaten dan 1 Kota memiliki banyak potensi ekonomi terhadap sektor-sektornya, tetapi masih belum dimanfaatkan secara optimal. Selain faktor fisik, hal tersebut juga dikarenakan kurangnya pemahaman masyarakat akan pentingnya pemanfaatan potensi ekonomi, disamping itu juga masih rendahnya kualitas sumber daya manusia yang ada sekarang ini pasca pemekaran kemarin. Oleh karena itu dibutuhkan suatu analisis terkait potensi ekonomi wilayah setiap daerah yang ada sehingga dapat meningkatkan investasi dan pembangunan daerah yang akhirnya dapat tercapai pengembangan wilayah yang diinginkan yang terimplementasi berkembangnya pertumbuhan ekonomi pada setiap tahunnya.

Dalam mendapatkan informasi berdasarkan teori yang telah dijelaskan, seperti teori pembangunan ekonomi daerah, teori sektor basis, dan teori pengembangan wilayah, maka untuk melakukan analisis pada setiap wilayah kabupaten dan kota dapat digunakan Analisis Deskriptif, Analisis Loqation Quotient, metode langsung dan tidak langsung (campuran). Metode-metode tersebut digunakan untuk menentukan potensi sektor ekonomi, pemetaan dan penentuan 
komoditas andalan apa saja yang ada di masing-masing Kabupaten dan kota di Provinsi Gorontalo.

Berdasarkan kondisi wilayah yang sangat berbeda karena keadaan tanah, iklim serta kebiasaan yang berkembang pada masyarakat maka pemanfaatan potensi pula selalu dipengaruhi berbagai faktor tersebut tetapi tidak akan menutup kemungkinan dapat terjadi perubahan pola konsumsi, produksi yang akan berkembang sehingga dapat mendorong meningkatnya penggalian dan pengembangan potensi yang dimiliki secara maksimal, terukur berdasarkan kebutuhan masyarakat dalam upaya pemenuhan kebutuhan keluarga dan otomatis akan berkembang pertumbuhan ekonomi itu sendiri.

Gambar 2.1. Alur Pikir Analisis Potensi Sektor Ekonomi dalam pengembangan pertumbuhan ekonomi di Provinsi Gorontalo

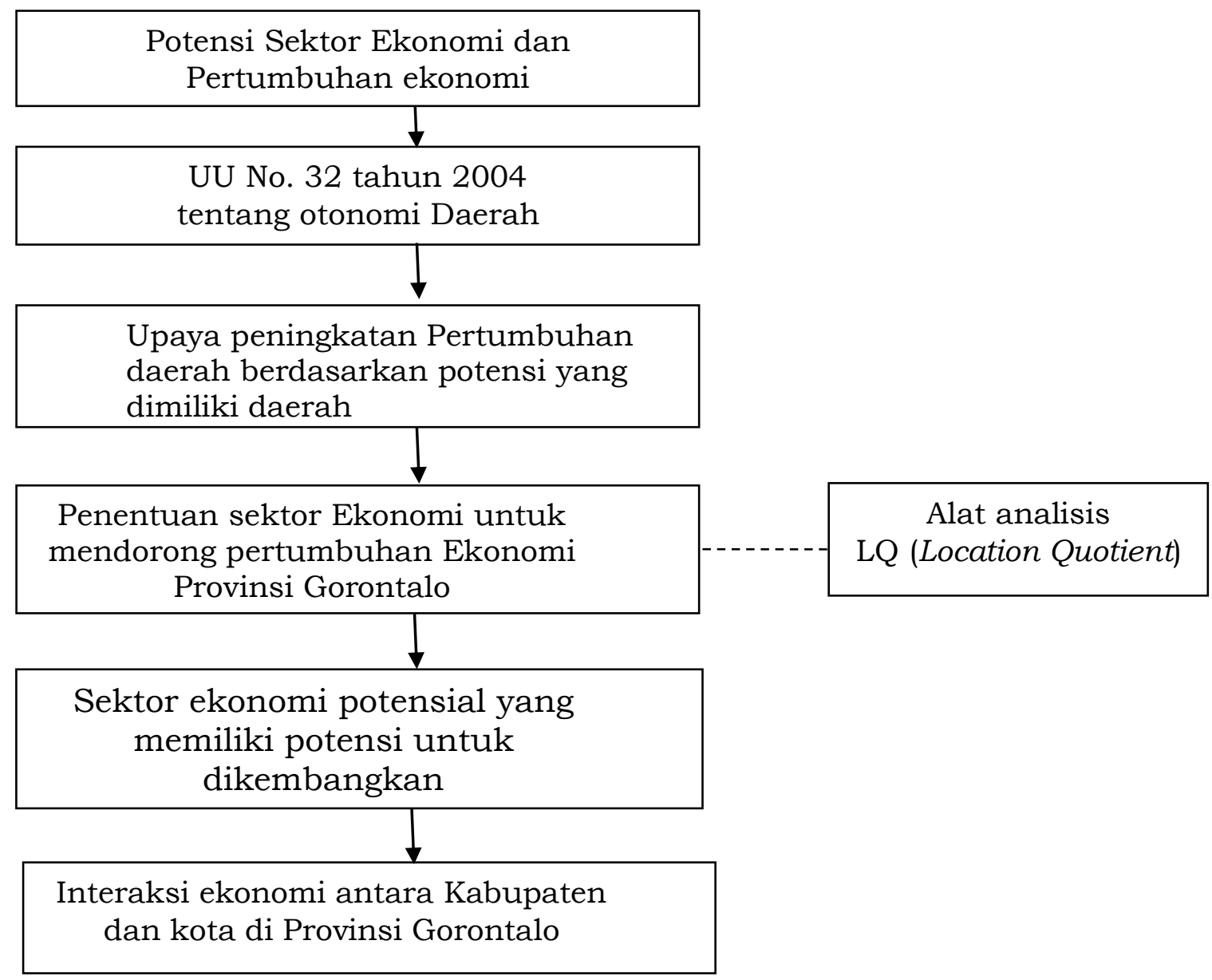

\section{METODE PENELITIAN}

\subsection{Variabel Penelitian dan Definisi Operasional}

3.1.1 Produk Domestik Bruto (PDRB) Produk Domestik Regional Bruto (PDRB) adalah semua barang dan jasa sebagai hasil dari kegiatankegiatan ekonomi yang beroperasi di wilayah domestik, tanpa memperhatikan apakah faktor produksinya berasal dari atau dimiliki 
oleh penduduk daerah tersebut (Kuncoro, 2013). Penelitian ini menggunakan PDRB menurut lapangan usaha berdasarkan harga konstan tahun 2000 Kabupaten/kota dan Provinsi Gorontalo pada tahun 2012-2016. Satuan dari PDRB yang digunakan yaitu dalam juta rupiah.

3.1.2. Penduduk, adalah semua orang yang berdomisili di wilayah geografis Republik Indonesia selama 6 bulan atau lebih dan atau mereka yang berdomisili kurang dari 6 bulan tetapi bertujuan untuk menetap (Statistik Indonesia). Penelitian ini menggunakan data jumlah penduduk kabupaten/ kota di Provinsi Gorontalo serta jumlah penduduk Provinsi Gorontalo pada tahun 2012-2016. Satuan dari variabel penduduk ini yaitu orang/ jiwa

\subsection{Metode Pengumpulan Data}

Metode pengumpulan data yang digunakan dalam penelitian ini adalah metode studi kepustakaan. Metode ini merupakan cara pengumpulan data dengan mengadakan penelitian kepustakaan yaitu dengan mempelajari bahan-bahan bacaan yang berhubungan dengan penelitian ini. Contohnya seperti buku-buku terbitan Pemerintah Provinsi Gorontalo dan Pemerintah Kabupaten dan kota melalui Badan Pusat Statistik (BPS), perpustakann dan download dari internet berupa artikel, jurnal dan buku-buku lainnya.

\subsection{Jenis dan Sumber Data}

\subsubsection{Jenis Data}

Penelitian ini menggunakan data sekunder yang berupa data time series dengan periode pengamatan 2012 -2016 (5 tahun). Data yang digunakan antara lain: Produk Domestik Regional Bruto (PDRB) menurut lapangan usaha atas dasar harga konstan tahun 2012 Provinsi Gorontalo serta Kabupaten Gorontalo dan Kota Gorontalo yang ada di provinsi tersebut. Data ini digunakan untuk mendukung alat analisis Location Quotient (LQ).

\subsubsection{Sumber Data}

Data yang digunakan dalam penelitian ini adalah data sekunder.Data sekunder merupakan data yang telah tersedia dan telah diproses oleh pihak-pihak lain sebagai hasil atas penelitian yang telah dilaksanakan. Sumber data tersebut antara lain:

- Badan Pusat Statistik (BPS) Provinsi Gorontalo

- Badan Pusat Statistik (BPS) Kabupaten dan Kota

\subsection{Metode Analisis}

\section{Analisis Location Quotient (LQ)}

Alat analisis Location Quotient (LQ) membandingkan besarnya kontribusi (Kabupaten dan kota ) terhadap besarnya peranan sektor tersebut pada wilayah referensi (Provinsi Gorontalo). Rumusnya adalah sebagai berikut:

$$
\mathrm{LQ}=\frac{\mathrm{Si} / \mathrm{S}}{\mathrm{Ni} / \mathrm{N}}
$$

Keterangan:

$L Q \quad$ : Indeks Location Quotient

$\mathrm{Si} \quad$ : PDRB Sektor i Kabupaten dan kota dalam juta rupiah

$S \quad$ : PDRB total Provinsi Gorontalo dalam juta rupiah

ni : PDRB sektor i di Provinsi Gorontalo dalam juta rupiah 
$N \quad$ : PDRB total Provinsi Gorontalo

Kriteria pengukuran LQ (Arsyad, 2002) yaitu:

a. LQ $<1$ artinya sektor i di Kabupaten / Kota lebih kecil dari sektor yang sama di Provinsi Gorontalo. Sektor tersebut bukan sektor basis dan kurang potensial untukdikembangkan. Bahkan sektor tersebut berperan untuk kebutuhan konsumsi hanya diwilayah studi saja.

b. $\quad$ LQ $=1$ artinya peranan relatif sektor i di Kabupaten / kota sama dengan peran relatif sektor i di Provinsi Gorontalo.

c. LQ > 1 artinya tingkat spesialisasi sektor i di Kabupaten dan Kota lebih besar dari sektor yang sama di Provinsi Gorontalo. Selain itu, dapat pula diartikan bahwa Kabupaten / Kota dapat mengekspor hasil output sektor i keluar daerah. Sektor tersebutlah yang merupakan sektor basis dan potensial untuk dikembangkan.

Nilai LQ yang didapat merupakan indeks LQ selama setahun. Namun, penelitian ini menggunakan periode pengamatan tahun 20122016. Oleh karena itu, untuk mendapatkan indeks LQ selama 5 tahun maka perlu dibuat rata-rata dari nilai LQ tahun 2012-2016 tersebut. Cara menghitung rata-rata sebagai berikut (Mason dan Lind, 2006) dalam Nisa :

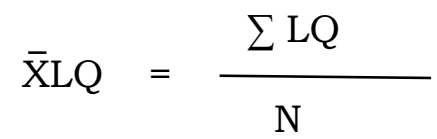

Keterangan:

XLQ : Rata-rata hitung indeks LQ

LQ : Indeks LQ

N : :Jumlah Data

Apabila selama periode penelitian sektor i selalu menjadi sektor basis, maka sektor tersebut merupakan sektor penting yang perlu mendapatkan perhatian lebih.

\section{HASIL PENELITIAN DAN PEMBAHASAN 4.1Analisis Potensi Sektor Ekonomi Kabupaten Gorontalo Dan Kota Gorontalo}

Kegiatan basis ekonomi (economic base thory) mendasarkan pandangannya bahwa laju pertumbuhan ekonomi suatu wilayah ditentukan oleh besarnya peningkatan ekspor dari wilayah tersebut. Kegiatan ekonomi dikelompokan atas kegiatan basis dan kegiatan non basis. Hanya kegiatan basis yang dapat mendorong pertumbuhan ekonomi wilayah.

Salah satu metode untuk memilah antara kegiatan basis dan kegiatan nonbasis adalah dengan menggunakan analisis Location Quatien (LQ) sebagai berikut :

$L Q i j=\frac{L_{i j} / L_{i}}{N_{i p} / N_{P}}$

Di mana :

Lqij = Location Quotient sektor i Kabupaten/Kota Gorontalo

Lij = Nilai tambah bruto (PDRB) sektor i di Kabupaten/Kota 
Gorontalo

Nip = Nilai tambah bruto (PDRB) sektor i Propinsi Gorontalo

$\mathrm{Li}=$ Total nilai tambah (PDRB) Kabupaten/Kota Gorontalo

$\mathrm{Np}=$ Total nilai tambah (PDRB) Propinsi Gorontalo

Apabila LQ > 1 artinya sektor tersebut merupakan sektor basis di Kabupaten/Kota Gorontalo. Sebaliknya, apabila LQ $<1$ maka sektor tersebut bukan merupakan sektor basis di Kabupaten/Kota Gorontalo.

Berikut ini adalah perhitungan sektor yang merupakan basis ekonomi di Kabupaten Gorontalo dan Kota Gorontalo tahun 2012 sampai 2016 melalui metode Location Quatien (LQ) sebagai berikut :

Hasil LQ Kabupaten Gorontalo tahun 2012 sampai 2017 dapat dilihat pada tabel berikut ini :

Tabel 4.1.1 Hasil Perhitungan LQ Kabupaten Gorontalo Tahun 2012-2016

\begin{tabular}{|c|l|c|c|c|c|c|}
\hline \multirow{2}{*}{ No } & \multicolumn{5}{|c|}{ Sektor } & \multicolumn{5}{|c|}{ Tahun } \\
\cline { 3 - 7 } & & $\mathbf{2 0 1 2}$ & $\mathbf{2 0 1 3}$ & $\mathbf{2 0 1 4}$ & $\mathbf{2 0 1 5}$ & $\mathbf{2 0 1 6}$ \\
\hline 1 & Pertanian, Kehutanan, Perikanan & 1,04 & 0,65 & 0,70 & 0,64 & 0,63 \\
\hline 2 & Pertambangan Dan Penggalian & 1,46 & 1,50 & 0,16 & 1,53 & 1,54 \\
\hline 3 & Industri Pengolahan & 1,03 & 1.05 & 1,04 & 1,04 & 1,04 \\
\hline 4 & Pengadaan Listrik dan Gas & 1,57 & 1,57 & 1,57 & 1,57 & 1,57 \\
\hline 5 & $\begin{array}{l}\text { Pengadaan Air, Pengelolaan } \\
\text { Sampah, Limbah dan Daur Ulang }\end{array}$ & 0,50 & 0,43 & 0,40 & 0,40 & 0,40 \\
\hline 6 & Kontruksi & 1,31 & 1,28 & 1,28 & 1,28 & 1,29 \\
\hline 7 & $\begin{array}{l}\text { Perdagangan Besar dan Eceran, } \\
\text { Reparasi Mobil dan Sepeda Motor }\end{array}$ & 0,79 & 0,78 & 0,76 & 0,76 & 0,76 \\
\hline 8 & Transportasi dan Pergudangan & 1,37 & 1,38 & 1,37 & 1,37 & 1,40 \\
\hline 9 & $\begin{array}{l}\text { Penyediaan Akomodasi, dan Makan } \\
\text { Minum }\end{array}$ & 0,90 & 0,89 & 0,63 & 0,88 & 1,00 \\
\hline 10 & Informasi dan Komunikasi & 0,64 & 1,08 & 1,56 & 1,06 & 1,04 \\
\hline 11 & Jasa Keuangan & 1,06 & 1,10 & 1,09 & 1,16 & 1,25 \\
\hline 12 & Real Estat & 0,93 & 0,56 & 0,31 & 0,56 & 0,55 \\
\hline 13 & $\begin{array}{l}\text { Jasa Perusahaan/Bussiness } \\
\text { Activities }\end{array}$ & 0,70 & 0.70 & 0,70 & 0,70 & 0,60 \\
\hline 14 & $\begin{array}{l}\text { Administrasi Pemerintahan, } \\
\text { Pertahanan dan Jaminan Sosial }\end{array}$ & 0,59 & 0,59 & 0,59 & 0,59 & 0,59 \\
\hline 15 & Jasa Pendidikan & 0,80 & 065 & 0,78 & 0.78 & 0,05 \\
\hline 16 & Jasa Kesehatan dan Kegiatan Sosial & 0,79 & 080 & 0,81 & 081 & 1,63 \\
\hline 17 & Jasa Lain-Lain & 0,82 & 0,83 & 0,82 & 0,83 & 0,87 \\
\hline
\end{tabular}

Sumber Data : Data Hasil Olahan Tahun 2017

Dari tabel diatas dapat dilihat bahwa berdasarkan perhitungan menggunakan rumus LQ, pada tahun 2012 LQ Kabupaten Gorontalo yang bernilai lebih dari satu adalah sektor pertanian, kehutanan, perikanan dan sektor pertambangan dan penggalian, sektor Industri Pengolahan, sektor pengadaan listrik dan gas, sektor konstruksi, sektor transportasi dan pergudangan, dan terakhir sektor jasa keuangan. Pada tahun 2013 terjadi perubahan dimana yang tetap 
bertahan menjadi sektor basis adalah sektor pertambagan dan penggalian, sektor Industri Pengolahan, sektor pengadaan listrik dan gas dan sektor jasa keuangan, asuransi dan beberapa sektor lainnya masih perlu dikembangkan menjadi sektor basis. Pada tahun 2014, masih seperti tahun sebelumnya, kemudian masih juga sektor pengangkutan dan komunikasi, sektor keuangan dan jasa perusahaan.

Selanjutnya, hasil LQ Kota Gorontalo tahun 2012 sampai 2016 dapat dilihat pada tabel berikut ini :

Tabel 4.1.2 Hasil Perhitungan LQ Kota Gorontalo Tahun 2012-2016

\begin{tabular}{|c|l|c|c|c|c|c|}
\hline \multirow{2}{*}{ No Sektor } & \multicolumn{5}{|c|}{ Tahun } \\
\cline { 2 - 6 } & & 2012 & 2013 & 2014 & 2015 & 2016 \\
\hline 1 & $\begin{array}{l}\text { Pertanian, Kehutanan, } \\
\text { Perikanan }\end{array}$ & 0,14 & 0,09 & 0,05 & 0,08 & 0,08 \\
\hline 2 & Pertambangan Dan Penggalian & 0,28 & 0,28 & 0,29 & 0,28 & 0,28 \\
\hline 3 & Industri Pengolahan & 1,14 & 1,12 & 1,12 & 1,13 & 1,12 \\
\hline 4 & Pengadaan Listrik dan Gas & 1,14 & 1,14 & 1,14 & 1,0 & 1,14 \\
\hline 5 & $\begin{array}{l}\text { Pengadaan Air, Pengelolaan } \\
\text { Sampah, Limbah dan Daur }\end{array}$ & 3,00 & 3,0 & 3,0 & 2,8 & 3,0 \\
\hline 6 & Kong & 1,16 & 1,16 & 1,16 & 1,13 & 1,15 \\
\hline 7 & $\begin{array}{l}\text { Perdagangan Besar dan Eceran, } \\
\text { Reparasi Mobil dan Sepeda } \\
\text { Motor }\end{array}$ & 1,37 & 1,36 & 1,37 & 1,36 & 1,33 \\
\hline 8 & Transportasi dan Pergudangan & 1,71 & 1,69 & 1,67 & 1,63 & 1,64 \\
\hline 9 & $\begin{array}{l}\text { Penyediaan Akomodasi, dan } \\
\text { Makan Minum }\end{array}$ & 2,09 & 2,09 & 2,22 & 2,21 & 2,53 \\
\hline 10 & Informasi dan Komunikasi & 1,74 & 1,88 & 1,88 & 1,86 & 1,85 \\
\hline 11 & Jasa Keuangan & 2,17 & 2,31 & 2,26 & 2,34 & 2,48 \\
\hline 12 & Real Estat & 2,09 & 2,17 & 2,19 & 0,56 & 2,24 \\
\hline 13 & $\begin{array}{l}\text { Jasa Perusahaan/Bussiness } \\
\text { Activities }\end{array}$ & 1,60 & 1,60 & 1,60 & 0,70 & 1,60 \\
\hline 14 & $\begin{array}{l}\text { Administrasi Pemerintahan, } \\
\text { Pertahanan dan Jaminan Sosial }\end{array}$ & 1,67 & 1,65 & 1,63 & 0,16 & 0,16 \\
\hline 15 & Jasa Pendidikan & 1,80 & 1,82 & 1,82 & 1,79 & 2,31 \\
\hline 16 & $\begin{array}{l}\text { Jasa Kesehatan dan Kegiatan } \\
\text { Sosial }\end{array}$ & 1,39 & 1,36 & 1,31 & 1,27 & 2,71 \\
\hline 17 & Jasa Lain-Lain & 1,46 & 1,46 & 1,49 & 1,53 & 0,02 \\
\hline
\end{tabular}

Sumber Data : Data Hasil Olahan Tahun 2017

Dari tabel diatas dapat dilihat bahwa berdasarkan perhitungan menggunakan rumus LQ, untuk tahun 2012 LQ Kota Gorontalo ratarata bernilai lebih dari satu hanya sektor yang bernilai kurang dari satu yaitu sektor pertanian dan sektor pertambangan dan penggalian. Pada tahun 2013 LQ Kota Gorontalo rata-rata sektor yang bernilai kurang dari satu yaitu sektor pertanian dan sektor pertambangan dan penggalian. Tetapi pada tahun 2015 sektor yang bernilai kurang 1 sedikit bertambah yaitu sektor pertanian dan sektor pertambangan 
dan penggalian, dan sektor real estat dan jasa perusahaan dan asuransi. Hal tersebut juga tidak jauh berbeda dengan tahun selanjutnya yaitu tahun 2016 .

\subsection{Pembahasan Penelitian}

Dari hasil analisis sektor basis dan non basis melalui metode Location Quatien (LQ) di Kabupaten Gorontalo dan Kota Gorontalo dapat dilihat bahwa secara umum tidak terdapat perbedaan yang besar antara sektor basis di Kabupaten Gorontalo dan di Kota Gorontalo. hal tersebut nampak pada tabel berikut ini :

Tabel 4.2.1 Hasil Perhitungan LQ Kabupaten Gorontalo Dan Kota Gorontalo Tahun 2012 sampai 2016

\begin{tabular}{|c|c|c|c|c|c|c|c|c|c|c|c|}
\hline \multirow{3}{*}{$\begin{array}{l}\text { No } \\
\text { Urut }\end{array}$} & \multirow{3}{*}{ Sektor } & \multicolumn{10}{|c|}{ Tahun/Wilayah } \\
\hline & & \multicolumn{5}{|c|}{ Kota Gorontalo } & \multicolumn{5}{|c|}{ Kabupaten Gorontalo } \\
\hline & & 2012 & 2013 & 2014 & 2015 & 2016 & 2012 & 2013 & 2014 & 2015 & 2016 \\
\hline 1 & $\begin{array}{l}\text { Pertanian, Kehutanan, } \\
\text { Perikanan }\end{array}$ & 0,14 & 0,09 & 0,05 & 0,08 & 0,08 & 1,04 & 0,65 & 0,70 & 0,64 & 0,63 \\
\hline 2 & $\begin{array}{l}\text { Pertambangan Dan } \\
\text { Penggalian }\end{array}$ & 0,28 & 0,28 & 0,29 & 0,28 & 0,28 & 1,46 & 1,50 & 0,16 & 1,53 & 1,54 \\
\hline 3 & Industri Pengolahan & 1,14 & 1,12 & 1,12 & 1,13 & 1,12 & 1,03 & 1.05 & 1,04 & 1,04 & 1,04 \\
\hline 4 & Pengadaan Listrik dan Gas & 1,14 & 1,14 & 1,14 & 1,0 & 1,14 & 1,57 & 1,57 & 1,57 & 1,57 & 1,57 \\
\hline 5 & $\begin{array}{l}\text { Pengadaan Air, } \\
\text { Pengelolaan Sampah, } \\
\text { Limbah dan Daur Ulang }\end{array}$ & 3,00 & 3,0 & 3,0 & 2,8 & 3,0 & 0,50 & 0,43 & 0,40 & 0,40 & 0,40 \\
\hline 6 & Kontruksi & 1,16 & 1,16 & 1,16 & 1,13 & 1,15 & 1,31 & 1,28 & 1,28 & 1,28 & 1,29 \\
\hline 7 & $\begin{array}{l}\text { Perdagangan Besar dan } \\
\text { Eceran, Reparasi Mobil dan } \\
\text { Sepeda Motor }\end{array}$ & 1,37 & 1,36 & 1,37 & 1,36 & 1,33 & 0,79 & 0,78 & 0,76 & 0,76 & 0,76 \\
\hline 8 & $\begin{array}{l}\text { Transportasi dan } \\
\text { Pergudangan }\end{array}$ & 1,71 & 1,69 & 1,67 & 1,63 & 1,64 & 1,37 & 1,38 & 1,37 & 1,37 & 1,40 \\
\hline 9 & $\begin{array}{l}\text { Penyediaan Akomodasi, } \\
\text { dan Makan Minum }\end{array}$ & 2,09 & 2,09 & 2,22 & 2,21 & 2,53 & 0,90 & 0,89 & 0,63 & 0,88 & 1,00 \\
\hline 10 & Informasi dan Komunikasi & 1,74 & 1,88 & 1,88 & 1,86 & 1,85 & 0,64 & 1,08 & 1,56 & 1,06 & 1,04 \\
\hline 11 & Jasa Keuangan & 2,17 & 2,31 & 2,26 & 2,34 & 2,48 & 1,06 & 1,10 & 1,09 & 1,16 & 1,25 \\
\hline 12 & Real Estat & 2,09 & 2,17 & 2,19 & 0,56 & 2,24 & 0,93 & 0,56 & 0,31 & 0,56 & 0,55 \\
\hline 13 & $\begin{array}{l}\text { Jasa } \\
\text { Perusahaan/Bussiness } \\
\text { Activities }\end{array}$ & 1,60 & 1,60 & 1,60 & 0,70 & 1,60 & 0,70 & 0.70 & 0,70 & 0,70 & 0,60 \\
\hline 14 & $\begin{array}{l}\text { Administrasi } \\
\text { Pemerintahan, Pertahanan } \\
\text { dan Jaminan Sosial }\end{array}$ & 1,67 & 1,65 & 1,63 & 0,16 & 0,16 & 0,59 & 0,59 & 0,59 & 0,59 & 0,59 \\
\hline 15 & Jasa Pendidikan & 1,80 & 1,82 & 1,82 & 1,79 & 2,31 & 0,80 & 065 & 0,78 & 0.78 & 0,05 \\
\hline 16 & $\begin{array}{l}\text { Jasa Kesehatan dan } \\
\text { Kegiatan Sosial }\end{array}$ & 1,39 & 1,36 & 1,31 & 1,27 & 2,71 & 0,79 & 080 & 0,81 & 081 & 1,63 \\
\hline 17 & Jasa Lain-Lain & 1,46 & 1,46 & 1,49 & 1,53 & 0,02 & 0,82 & 0,83 & 0,82 & 0,83 & 0,87 \\
\hline
\end{tabular}

Sumber data : Data Diolah Tahun 2017

Dari tabel diatas dapat dilihat bahwa sektor industri pengolahan, sektor sektor listrik gas dan air bersih dan sektor kontruksi, sektor transpotasi dan pergudangan, sektor jasa keuangan, sama-sama merupakan sektor basis di Kabupaten Gorontalo dan di Kota Gorontalo. 
Yang berbeda adalah, di Kabupaten Gorontalo pada tahun 2012-2016, sektor pertanian menjadi sektor basis sedangkan di Kota Gorontalo tidak merupakan sektor basis. Adapun sektor listrik gas dan air bersih, sektor bangunan serta sektor perdagangan hotel dan restoran merupakan sektor basis di Kota Gorontalo, sedangkan di Kabupaten Gorontalo tidak menjadi sektor basis.

Sektor pertanian pada akhirnya menjadi sektor basis di Kabupaten Gorontalo selama periode 2012 sampai tahun 2016, hal tersebut jelas karena sektor ini merupakan sektor yang memberikan kontribusi yang besar bagi keseluruhan PDRB di Kabupaten Gorontalo. Sektor ini juga menyerap tenaga kerja terbanyak dari penduduk yaitu sebesar kurang lebih $70 \%$ dari total tenaga kerja, dengan luas lahan produktif $187.688 \mathrm{Ha}$. selain itu didukung oleh program kebijakan pembangunan pertanian oleh pemerintah daerah yang semakin mendorong produksi petani baik melalui pemberian bantuan pupuk, benih, dan teknologi pertanian. Salah satu hal yang penting adalah luas lahan pertanian di Kabupaten Gorontalo lebih besar dibandingkan di Kota Gorontalo.

Adapun sektor pengadaan air bersih, persampahan di Kota Gorontalo menjadi sektor basis di Kota Gorontalo, mengingat hampir seluruh masyarakat atau rumah tangga penduduk di Kota Gorontalo telah menggunakan air sedangkan di Kabupaten Gorontalo, beberapa desa yang letaknya berada di pelosok kabupaten belum mendapatkan akses terhadap jasa air minum. Untuk hal air bersih, di Kota Gorontalo sebagian besar masyarakat merupakan konsumen dari perusahaan daerah air minum (PDAM) yang tersebar diseluruh kecamatan, sedangkan di Kabupaten Gorontalo, konsumen PDAM adalah hanya sebagian masyarakat yang berada di wilayah ibukota kabupaten dan sekitarnya. Daerah kecamatan yang jauh dari ibukota kabupaten masih menggunakan air sungai bahkan di beberapa daerah dataran tinggi seperti di Kecamatan Pulubala dan sekitarnya masih kesulitan terhadap mendapatkan air.

\subsection{Simpulan}

\section{SIMPULAN DAN SARAN}

Adapun penelitian ini telah melalui proses pengkajian lebih terfokus berdasarkan data dan formulasi analisis yang digunakan sehingga peneliti membuat beberapa kesimpulan yang dapat dijadikan sebagai hasil akhir serta digunakan bagi kebijakan selanjutnya terhadap proses pembangunan bagi peningkatan kesejahtraan masyarakat, adalah sebagai berikut :

1. Bahwa berdasarkan hasil perhitungan LQ diperoleh bahwa di Kabupaten Gorontalo dan di Kota Gorontalo yang menjadi sektor basis adalah sektor industri pengolahan, sektor sektor listrik gas dan air bersih dan sektor kontruksi, sektor transpotasi dan pergudangan, sektor jasa keuangan

2. Bahwa untuk Kabupaten Gorontalo periode tahun 2012-2016 yang menjadi sektor basis yang utama adalah sektor pertanian sedangkan untuk Kota Gorontalo yang menjadi sektor basisnya adalah sektor 
listrik gas dan air bersih, sektor bangunan serta sektor perdagangan hotel dan restoran.

3. Bahwa dari beberapa sektor yang menjadi basis di Kabupaten Gorontalo maupun di Kota Gorontalo selang periode 2012-2016 tersebut sangat memberikan kontribusi terbesar bagi penyumbang PDRB dan penyerap tenaga kerja terbanyak dari penduduk pada masing-masing wilayah kabupaten dan kota di Provinsi Gorontalo.

\subsection{Saran}

1. Dengan diperolehnya hasil perhitungan LQ dari beberapa sektor yang menjadi basis ekonomi maka pemerintah perlu memperhatikan upaya pengembangannya secara terus menerus melalui berbagai kebijakan yang dapat memberikan peluang secara mandiri dan peningkatan penganggarannya.

2. Dengan terbentuknya sektor basis pada kedua wilayah tersebut maka dapat memberikan peluang bagi pada pengusaha untuk dapat memberikan investasinya pada berbagai sektor untuk dikembangkan terutama diarahkan pada usaha penyerapan tenaga kerja dan produktifitas yang sangat tinggi tanpa harus mengabaikan sektor non basis sebagai pendukung sektor utama.

selain itu didukung oleh program kebijakan pembangunan pertanian oleh pemerintah daerah yang semakin mendorong produksi petani baik melalui pemberian bantuan pupuk, benih, dan teknologi pertanian. Salah satu hal yang penting adalah luas lahan pertanian di Kabupaten Gorontalo lebih besar dibandingkan di Kota Gorontalo.

\section{REFERENSI}

Cahyono, Andi S, dan Wijaya, Wisnu Wahyu, 2014, Identifikasi Sektor Unggulan dan Ketimpangan Pendapatan Antar Kabupaten di Sub

Das Bengawan Solo Hulu, Jurnal : Penelitian Sosial dan Ekonomi Kehutanan Vol. 11 No. 1 Maret 2014, Hal. 32 - 43, diakses tanggal 17 April 2017

Daryanto, Arief dan Hafizrianda, Yundy, 2012, Model-Model Kuantitatif Untuk Perencanaan pembangunan Ekonomi Daerah Edisi ke dua, Penerbit PT Penerbit IPB Press, Bogor

Jhingan, M.L, 2012, Ekonomi Pembangunan dan Perencanaan Cetakan ke Empat Belas, Penerbit PT Raja Grafidon

Ma'ruf, Ahmad 1 dan Wihastuti, Latri, (2008), Pertumbuhan Ekonomi Indonesia, Jurnal Ekonomi dan Studi Pembangunan Volume 9, Nomor 1, April 2008:44-55, Universitas Muhammadiyah Yokyakarta, diakses tanggal 29 Juli 2017

Nisa, Hoirun, 2014, Analisis Potensi dan Pengembangan Wilayah Kabupaten Lebak Provinsi Banten, Skripsi, Fakultas Ekonomika dan Bisnis Universitas Diponegoro, Semarang

Nugroho, Iwan dan Dahuri, Rokhmin, 2012, Pembangunan Wilayah Perspektif ekonomi, Sosial dan Lingkungan, Cetakan Kedua, Penerbit LP3ES, Jakarta

Simanjuntak, Damiana dan Sirojuzilam, 2013, Potensi Wilayah dalam Kawasan Agropolitan di Kabupaten Toba Samosir, Jurnal Ekonomi dan Keuangan Vol. 1, No. 3, Februari 2013, diakses tanggal 21 Juli 2017 
Sjafrizal, 2014, Ekonomi Wilayah dan Perkotaan, Penerbit PT Raja Grafido Persada, Jakarta

Subandi, 2011, Ekonomi Pembangunan Cetakan ke satu, Penerbit Alfabeta, Bandung

Todaro, Michael P dan Smith, Steven C, 2003, Pembangunan Ekonomi Dunia Ke Tiga, Edisi ke Delapan, Penerbit Erlangga, Jakarta

Umami, Reza Rosyida, 2014, Analisis Sektor Potensial Pengembangan Wilayah Guna Mendorong Pembangunan Daerah di Kabupaten Pacitan, Penerbit Fakultas Ekonomika dan Bisnis Universitas Diponegoro, Semarang, diakses 20 Juli 2017

Wijaya, Bayu dan Dwi Atnadji, Hastarini, Analisis Pengembangan Wilayah dan Sektor Potensial Guna Mendorong Pembangunan di Kota Salatiga, Jurnal Dinamika Pembangunan Vol. 3 No. 2 Desember 2006, Universitas Diponegoro. Di Akses tanggal 22 Juli 2017

Provinsi Gorontalo dalam angka tahun 2012, penerbit BPS Provinsi Gorontalo, tahun 2013

Provinsi Gorontalo dalam angka tahun 2013, penerbit BPS Provinsi Gorontalo, tahun 2014

Provinsi Gorontalo dalam angka tahun 2014, penerbit BPS Provinsi Gorontalo, tahun 2015

Provinsi Gorontalo dalam angka tahun 2015, penerbit BPS Provinsi Gorontalo, tahun 2016

Provinsi Gorontalo dalam angka tahun 2016, penerbit BPS Provinsi Gorontalo, tahun 2017

Kabupaten Gorontalo dalam angka tahun 2012, penerbit BPS Kabupaten Gorontalo tahun 2013

Kabupaten Gorontalo dalam angka tahun 2013, penerbit BPS Kabupaten Gorontalo tahun 2014

Kabupaten Gorontalo dalam angka tahun 2014, penerbit BPS Kabupaten Gorontalo tahun 2015

Kabupaten Gorontalo dalam angka tahun 2015, penerbit BPSKabupaten Gorontalo tahun 2016

Kabupaten Gorontalo dalam angka tahun 2016, penerbit BPS Kabupaten Gorontalo tahun 2017

Kota Gorontalo dalam angka tahun 2013, penerbit BPS Kota Gorontalo, tahun 2013-201 